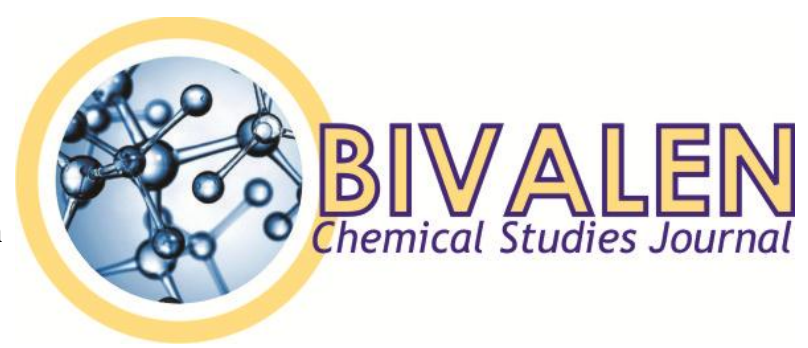

\title{
ANALISIS KADAR ALKOHOL PADA TAPE UMBI TALAS (Colocasia esculenta) DENGAN VARIASI MEREK RAGI YANG DIJUAL DI SEKITAR KOTA SAMARINDA
}

\section{ANALYSIS OF ALCOHOL LEVEL IN TAPE UMBI TALAS (Colocasia esculenta) WITH YEAST BRAND VARIATION FOR SALE AROUND SAMARINDA}

\author{
Muflihah*, Yuyun Maisyaroh \\ Program Studi sarjana Pendidikan Kimia, Fakultas Keguruan dan Ilmu Pendidikan, Universitas Mulawarman, \\ Samarinda, Kalimantan Timur, Indonesia \\ *Corresponding Author: ikha.prabowo@yahoo.co.id
}

\begin{abstract}
ABSTRAK
Talas (Colocasia esculenta) tergolong umbi-umbian yang banyak dibudidayakan di Provinsi Kalimantan Timur. Talas mengandung karbohidrat dan unsur mineral yang cukup tinggi. Di Indonesia umbi-umbian sejenis talas selain digoreng, direbus, dan dibuat keripik biasanya oleh masyarakat dibuat sebagai tape sebagai variasi dalam pengolahan bahan. Tape yang difermentasi akan menghasilkan alkohol (etanol), asam laktat, dan hidrogen. Oleh karena itu tujuan dari penelitian ini adalah untuk mengetahui kadar alkohol yang terdapat pada tape umbi talas dengan variasi penggunaan merek ragi $(0,5 \mathrm{~g})$. Analisa alkohol dilakukan menggunakan proses destilasi memanfaatkan perbedaan titik didih dua cairan yang akan dipisahkan. Hasil yang diperoleh dari proses destilasi kemudian diukur menggunakan alkoholmeter untuk mengetahui kadar alkohol pada tape umbi talas sampel. Hasil penelitian menunjukkan kadar alkohol tape talas dengan ragi merek NKL menghasilkan kadar alkohol sebesar $10 \%$, ragi GENDANG 8,7\%, dan ragi merek menghasilkan kadar alkohol sebesar 11,3\%.
\end{abstract}

Kata Kunci : alkohol, destilasi, fermentasi, ragi, talas, tape

\begin{abstract}
Taro (Colocasia esculenta) are widely cultivated in East Kalimantan Indonesian. Taro is on of source of carbohydrates and mineral elements. The taro tubers usually process by frying, boiling, or make as chips snack. Sometimes it is also fermented as a variation of processing. Fermented taro will produce alcohol (ethanol), lactic acid, and hydrogen. Therefore the aim of this study was to known alcohol the level of alcohol in the fermented taro tuber which were made using 3 different brands of yeast. Alcohol content were separated using distillation process and measured by alkoholmeter. The results showed the yeast biard of alcohol greet were that the NKL brand, GENDANG and unknown brand obtained alcohol content 10\%, 8,7\%, and $11,3 \%$ respectively.
\end{abstract}

Keywords: alcohol, distillation, fermented taro, yeast

\section{PENDAHULUAN}

Talas umumnya tumbuh subur di daerah negara-negara tropis. Bahan pangan ini memiliki kombinasi dalam menjaga ketahanan pangan didalam negeri dan juga berpotensi sebagai barang ekspor yang dapat menghasilkan keuntungan.

Kultur talas memiliki banyak ragam terutama di daerah-daerah yang merupakan sentra produksi talas seperti Bogor, Malang, Mentawai, Lampung, Sulawesi Selatan, Sulawesi Utara dan Papua yaitu jenis Colocasia, Cyrtosperma, Alocasia, dan Xanthosoma. Dari sekian banyak jenis talas yang telah diketahui, talas yang paling banyak dibudidayakan di seluruh kepulauan Indonesia adalah jenis Colocasia, yaitu Colocasia esculenta yang juga banyak dijumpai di Provinsi Kalimantan Timur.

Provinsi Kalimantan Timur merupakan salah satu sentra produksi talas di Indonesia, namun pengolahan umbi talas ini belum optimal dalam 
konsumsi rumah tangga. Hal ini terbukti dari segi penjualan talas di pasar-pasar tradisional, makanan olahan dari talas sangat jarang ditemui.

Talas mengandung unsur mineral dan nutrisi penting lainnya. Umbi talas juga berpotensi sebagai sumber karbohidrat yang cukup tinggi. Umbi talas juga mengandung vitamin A, B1 dan sedikit vitamin C. salah satu olahan talas yang masih jarang ditemui adalah tape talas.

Tape merupakan bentuk hasil olahan tradisional yang sudah tidak asing lagi bagi masyarakat Indonesia. Tape dapat terbuat dari umbiumbian yang difermentasi dan akan menghasilkan etanol, asam laktat, dan hidrogen. Beberapa komponen lain juga dapat dihasilkan dari fermentasi seperti asam butirat dan aseton. Pembuatan tape melibatkan banyak mikroorganisme yang terdapat di dalam ragi tape. Ragi dikenal sebagai bahan yang umumnya digunakan dalam fermentasi untuk menghasilkan alkohol dalam air, anggur, dan minuman beralkohol lainnya.

Alkohol yang dihasilkan dalam proses fermentasi pada tape dihasilkan dari gula yang merupakan hasil aktivitas fermentasi sel khamir. Selain digunakan sebagai variasi makanan, tape dapat digunakan untuk meningkatkan kesehatan badan karena mengandung alkohol. Orang yang merasa lemah dan badan yang kurang nyaman bisa mengkonsumsi tape untuk meningkatkan kondisi kesehatan badan. Tape akan membuat badan menjadi lebih hangat dan kadar alkohol yang dihasilkan dalam proses fermentasinya. Sehingga besarnya kadar alkohol dalam tape akan mempercepat proses penghangatan tubuh dan akan meningkatkan kondisi kesehatan badan yang kurang nyaman tersebut. Selain itu, besarnya kadar alkohol yang dihasilkan dari proses fermentasi tape bermanfaat untuk menghilangkan jerawat. Alkohol yang dihasilkan berfungsi untuk menetralisir lemak dalam tubuh, dimana salah satu penyebab jerawat adalah lemak yang berlebihan dalam kulit wajah. Dengan mengkonsumsi tape, maka alkohol akan menetralisir lemak yang berlebihan di kulit wajah sehingga bermanfaat untuk menghilangkan jerawat.

Penentuan kadar alkohol terhadap tape telah banyak dilakukan oleh peneliti-peneliti lainnya. Contohnya Penelitian yang dilakukan oleh Hasanah (2008) yang meneliti pengaruh lama fermentasi terhadap kadar alkohol tape singkong (Manihot utilissima Pohl) memperoleh kadar alkohol tape singkong sebesar $4.904 \%$.

Berdasarkan latar belakang di atas, penulis tertarik untuk melakukan penelitian mengenai pengaruh variasi merek ragi tape terhadap kadar alkohol yang dihasilkan dalam olahan tape talas (Colocasia esculenta).

\section{METODE PENELITIAN}

Sampel pada penelitian ini adalah umbi talas yang diperoleh dari pedagang di pasar Segiri, Samarinda dan variasi ragi tape yang diperoleh di sekitar Samarinda.

\section{Proses Pembuatan Tape Umbi Talas}

Gambar 3.1 menjelaskan proses pembuatan

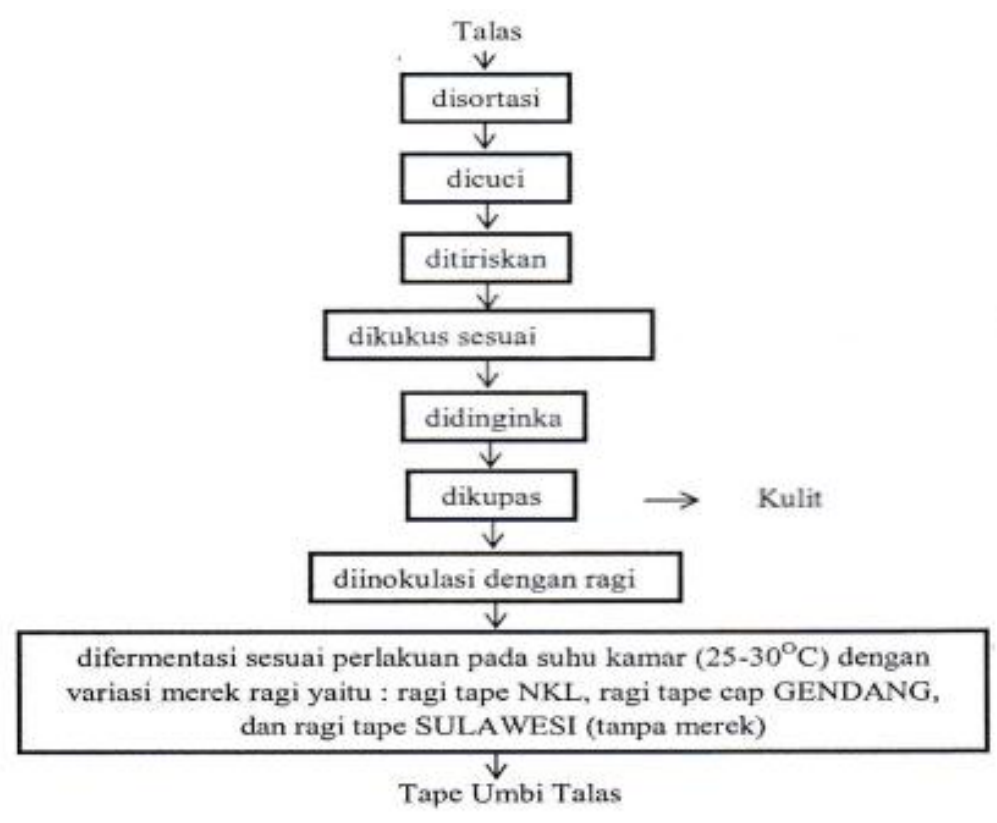

Gambar 3.1 Proses Pembuatan Tape Umbi 
tape talas dari penyortiran umbi talas yang akan diolah hingga membentuk produk tape umbi talas.

\section{Destilasi Pada Hasil Fermentasi Tape Umbi Talas}

Dalam penelitian ini digunakan perlakuan dengan variasi jenis ragi tape yang berbeda dengan simbol $\mathrm{X}_{1}, \mathrm{X}_{2}$, dan $\mathrm{X}_{3}$. Pada setiap 10 gram sampel, pengulangan dilakukan sebanyak tiga kali dengan simbol $t_{1}, t_{2}$, dan $t_{3}$. Penentuan kadar Alkohol, menggunakan alkoholmeter. Data yang diperoleh dianalisis dengan menggunakan Analisis Anova satu Arah $(\alpha=0,05)$. Alkohol pada fermentasi tape talas.

\section{Pembahasan}

Pada pembuatan tape, sebelum difermentasi umbi talas masih berbentuk umbi seperti pada umumnya. Namun setelah mengalami fermentasi, umbi tersebut mengalami perubahan bentuk dan menghasilkan air yang mengandung alkohol serta menimbulkan rasa asam dan manis. Kondisi tersebut disebabkan karena pada umbi talas diberikan ragi yang merupakan mikroorganisme yang berfungsi mengubah glukosa menjadi alkohol dan menghasilkan air. Karena fermentasi pada talas membutuhkan kadar air yang cukup untuk ragi agar

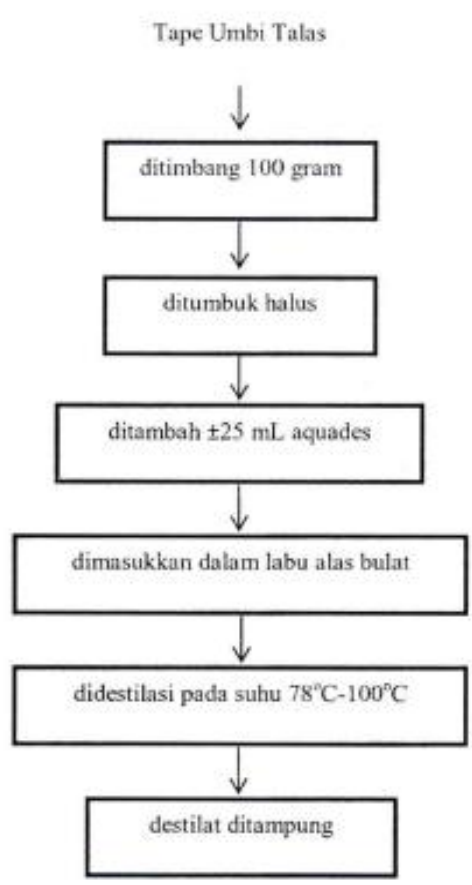

\section{Gambar 3.2 Destilasi Alkohol Pada Tape Umbi Talas}

\section{HASIL DAN PEMBAHASAN}

\section{Hasil Pengamatan}

Kadar Alkohol (\%) yang Terdapat Pada Sampel dengan Variasi merek ragi yang berbeda.

Tabel 1

Persentase kadar alkohol yang terkandung dalam tape ubi talas

\begin{tabular}{|l|c|c|c|c|}
\hline \multirow{2}{*}{ Merek Ragi } & \multicolumn{3}{|c|}{$\begin{array}{c}\text { Pengulangan } \\
(\%)\end{array}$} & $\begin{array}{c}\text { Rata- } \\
\text { rata }\end{array}$ \\
\cline { 2 - 4 } & 1 & 2 & 3 & $(\%)$ \\
\hline NKL & 10 & 10 & 10 & 10 \\
\hline GENDANG & 8 & 9 & 9 & 8,7 \\
\hline TANPA MEREK & 11 & 11 & 12 & 11,3 \\
\hline
\end{tabular}

bisa hidup. Oleh karena itu, umbi talas harus dikukus terlebih dahulu.

Talas tidak boleh terkena air, jika sudah diberi ragi, karena akan mematikan ragi (bakteri) sehingga proses fermentasi tidak berjalan sempurna. Banyaknya ragi yang digunakan disesuaikan dengan jumlah umbi talas yang akan dibuat tape. Bila terlalu banyak akan mempercepat proses fermentasi dan menyebabkan rasa tape menjadi sangat manis. Talas juga diletakkan atau disimpan dalam tempat yang kedap udara. Karena jika terkena oksigen, proses fermentasi juga akan gagal.

Talas mengandung karbohidrat yang dapat diubah oleh ragi menjadi alkohol dan air. Dimana dalam proses ini polisakarida akan dirombak atau dipecah menjadi disakarida dengan menggunakan panas. Panas yang dihasilkan berasal dari ragi tape 
tersebut. Kemudian disakarida akan dipecah menjadi glukosa dan fruktosa dengan bantuan enzim amilase yang berasal dari kapang. Jika ragi semakin banyak maka enzim amilase juga akan semakin banyak sehingga glukosa dan fruktosa juga akan semakin banyak dan rasanya akan semakin manis. Dalam proses selanjutnya glukosa akan dirombak menjadi alkohol dan $\mathrm{CO}_{2}$ oleh bantuan invertase yang berasal dari khamir atau bakteri. Semakin banyak jumlah glukosa maka akan semakin banyak juga alkohol yang dihasilkan. Apabila fermentasi berlangsung lebih lama maka produksi alkohol juga akan semakin banyak.

Penentuan kadar alkohol dalam tape talas dilakukan melalui proses destilasi terhadap sampel yang dilakukan. Dasar pemisahan destilasi adalah perbedaan dua titik dua cairan atau lebih. Jika campuran dipanaskan maka komponen yang titik didihnya lebih rendah akan menguap lebih dulu. Air mendidih pada 100C dan etanol mendidih pada sekitar $77 \mathrm{C}$ pada tekanan atmosfer. Perbedaan dalam titik didih inilah yang memungkinkan pemisahan campuran etanol air.

Hasil dari destilasi dan pengukuran kadar alkohol sampel tape talas dalam penelitian ini diperoleh bahwa tape umbi talas yang diberikan ragi yang berbeda-beda memiliki hasil kadar alkohol yang berbeda pula yaitu tape talas dengan penggunaan merek ragi tape NKL diperoleh kadar alkohol rata-rata sebesar 10\%, kemudian untuk tape talas dengan penggunaan merek ragi tape GENDANG diperoleh kadar alkohol rata-rata sebesar $8,7 \%$, sedangkan untuk tape talas dengan penggunaan ragi tanpa merek diperoleh kadar alkohol rata-rata sebesar $11,3 \%$ dengan dilakukannya tiga kali pengulangan destilasi untuk ketiga sampel tersebut. Berdasarkan hasil destilasi yang telah dilakukan terhadap sampel tape umbi talas dengan bentuk perlakuan dibedakan merek ragi yang digunakan dalam proses fermentasi. Hasil yang didapatkan diketahui bahwa terdapat pengaruh dalam penggunaan merek ragi terhadap kadar alkohol yang dihasilkan pada fermentasi tape umbi talas. Pengaruh perbedaan kadar alkohol yang dihasilkan pada tiap merek ragi ini dapat disebabkan oleh perbedaan komposisi mikroba serta perbedaan cara pengemasan tiap merek ragi yang digunakan.

Jika diamati pada tiap merek ragi terdapat komposisi penyusun masing-masing ragi yang bisa saja menjadi penyebab perbedaan komposisi gizi dan kandungan mikroba dalam ragi yang tidak sama tersebut. Komposisi ragi tape dengan merek NKL (na kok liong) terdiri dari beras, bawang putih, cabe jawa, lada putih dan adas. Kemudian komposisi ragi tape dengan merek GENDANG terdiri dari beras, bawang putih, merica, dan bahan rempah lainnya. Sedangkan komposisi ragi tape yang tanpa merek tidak diketahui komposisi penyusun ragi tape tersebut sebab ragi tape dikemas dalam wadah tanpa merek. Perbedaan komposisi gizi dan kandungan mikroba dalam ragi yang tidak sama tersebut dapat mempengaruhi proses fermentasi yang terjadi.

Penggunaan ragi tape dalam pembuatan tape talas sangatlah menentukan hasil tape yang diinginkan, dimana ragi tape yang ada di pasaran mempunyai beberapa macam merek dagang, antara satu merek dengan merek lainnya terdapat perbedaan komposisi mikroba, dan ini akan mempengaruhi tekstur, penampakan, serta cita rasa tape talas yang dihasilkan. Perbedaan mutu tape dapat disebabkan oleh beberapa faktor, yaitu: bahan baku dan cara pembuatan ragi tape, kandungan mikroorganisme ragi tape, dosis ragi sebagai inokulum, penyimpanan ragi, suhu dan lama inkubasi atau fermentasi tape.

Gula yang terbentuk selama fermentasi sebagai akibat adanya perbedaan aktivitas yang dilakukan mikroba pada ragi. Kelompok kapang yang digunakan dalam fermentasi tape adalah golongan jenis Mucor dan Rhizopus. Sedangkan kelompok khamir adalah Candida, Saccharomyces, Hansenula, dan sebagainya. Perbedaan kandungan mikroba yang berbeda pada merek ragi akan berpengaruh pada kestabilan pertumbuhan masing-masing mikroba. Ketika pertumbuhannya mengalami perbedaan, maka dapat mengakibatkan hasil fermentasinya berbeda.

Selain itu perbedaan bisa terjadi karena perbedaan cara pengemasan tiap merek ragi yang digunakan. Pada ragi tape dengan merek NKL dan GENDANG ragi dijual dengan kemasan kedap udara dan tertera jelas merek serta komposisinya. Sedangkan untuk ragi tape tanpa merek dijual dalam wadah terbuka biasa tanpa merek dagang. Perbedaan cara pengemasan ragi tersebut bisa menjadi salah satu penyebab perbedaan kadar alkohol pada tiap merek ragi, karena ragi tape yang dikemas dengan kemasan kedap udara lengkap dengan merek dagang membutuhkan biaya yang lebih besar sehingga harga jual ragi dengan merek ini akan lebih mahal dibanding dengan ragi tape yang dikemas dengan wadah plastik biasa yang lebih ekonomis. 
Ragi tape yang lebih ekonomis akan lebih digemari oleh masyarakat sehingga ragi tape tanpa merek ini akan lebih cepat habis jika dijual dipasaran sedangkan ragi dengan merek NKL dan GENDANG membutuhkan waktu yang lebih lama karena harga jual yang lebih mahal. Ragi tape yang cepat habis jika dijual akan lebih sering diperbarui sehingga ragi tape tersebut memiliki komposisi ragi yang masih baik, sedangkan ragi yang lama habisnya akan menumpuk di pedagang dan kualitasnya kan menurun dengan berangsurnya waktu penyimpanan ragi tersebut sehingga dapat mempengaruhi kualitas hasil fermentasi tape umbi talas yang dihasilkan.

Kemudian berdasarkan hasil uji organoleptik yang telah dilakukan pada tape talas dengan variasi merek ragi yang digunakan diperoleh data sebagai berikut: rata-rata hasil indikator warna sebesar 2.6, aroma 2.9 , rasa 2.7 dan tekstur 2.6 pada tape umbi talas dengan penggunaan merek ragi NKL pada kisaran nilai maksimum adalah 3. Tape talas dengan penggunaan merek ragi GENDANG diperoleh hasil rata-rata indikator warna sebesar 2.4, aroma 3.0, rasa 2.2, dan tekstur 2.2 pada kisaran nilai maksimum adalah 3. Sedangkan hasil untuk tape talas dengan penggunaan ragi tanpa merek diperoleh hasil ratarata indikator warna sebesar 2.6, aroma 2.8 , rasa 3 , dan tekstur 2.7 pada kisaran nilai maksimum adalah 3. Berdasarkan hasil uji organoleptik tersebut dari 10 orang pemelitis yang telah merasakan tape talas yang dijadikan sampel dapat dikatakan bahwa tape talas yang diteliti dapat diterima oleh masyarakat karena hasil yang diperoleh menunjukkan hasil yang cukup dengan tidak adanya hasil rata-rata yang dengan kriteria tidak suka.

Besarnya kadar alkohol yang dihasilkan akan meningkatkan citra rasa tape yang dihasilkan sebab besarnya kadar alkohol yang dihasilkan dari penguraian glukosa oleh khamir. Khamir mempunyai kemampuan untuk memecah karbohidrat menjadi alkohol dan karbondioksida. Proses ini diketahui sebagai fermentasi alkohol yaitu proses anaerob. Khamir mempunyai sekumpulan enzim yang diketahui sebagai zymase yang berperan pada fermentasi senyawa gula, seperti glukosa menjadi etanol dan karbondioksida.

$$
\mathrm{C}_{6} \mathrm{H}_{12} \mathrm{O}_{6} \rightarrow 2 \mathrm{C}_{2} \mathrm{H}_{5} \mathrm{OH}+2 \mathrm{CO}_{2}
$$

$$
\text { Glukosa Etanol }
$$

Jika $\mathrm{O}_{2}$ berlebihan, sel khamir akan melakukan respirasi secara aerobik, dalam keadaan ini enzim khamir dapat memecah senyawa gula lebih sempurna, dan akan dihasilkan karbondioksida dan air.

$$
\mathrm{C}_{6} \mathrm{H}_{12} \mathrm{O}_{6}+6 \mathrm{O}_{2} \rightarrow 6 \mathrm{CO}_{2}+6 \mathrm{H}_{2} \mathrm{O}
$$

Berdasarkan standar SNI No. 01-4018-1996, persentase kadar alkohol yang diperbolehkan dalam bahan makanan dan minuman maksimal berkisar antara $8-20 \%$. Sehingga besar kadar alkohol yang dihasilkan pada tape umbi talas tergolong masih sesuai dengan batas maksimum yang ditentukan oleh SNI.

Selain digunakan sebagai variasi makanan tape dapat digunakan untuk meningkatkan kesehatan badan karena mengandung alkohol. Orang yang merasa lemah dan badan yang kurang nyaman bisa mengkonsumsi tape untuk meningkatkan kondisi kesehatan badan. Tape akan membuat badan menjadi lebih hangat dengan kadar alkohol yang dihasilkan dalam proses fermentasinya.

\section{PENUTUP}

\section{Simpulan}

Umbi Talas yang kaya akan kandungan karbohidrat dapat dimanfaatkan sebagai panganan berupa tepe. Proses pembuatan tape menggunakan prinsip fermentasi dengan bantuan ragi tape. Penggunaan merek ragi tape dalam pembuatan tape talas dapat mempengaruhi hasil tape talas yang diperoleh berupa hasil kadar alkohol yang berbedabeda pada tiap merek ragi yang digunakan. Hasil analisis kadar alkohol pada tape umbi talas dengan penggunaan merek ragi NKL sebesar $10 \%$, pada penggunaan merek ragi GENDANG sebesar 8,7\%, sedangkan ragi tanpa merek sebesar 11,3\%.

\section{DAFTAR PUSTAKA}

ASAIHL. 1985. Food Technology and Nutrition. Yogyakarta; UGM-Press.

Buckle, K. A.et all. 1985. Ilmu Pangan Penerjemah Hari Purnomo, Adiono. Jakarta; UI Press.

Depkes RI. 1992. UU RI No.23 Tahun 1992 Tentang Kesehatan. Depkes RI.

Desrosier. 1998. Teknologi Pengawetan Pangan. Penerjemah M .Muljohardjo. Jakarta; UI-Press

Dwidjoseputro. 1988. Dasar-dasar Mikrobiologi Pangan. Jakarta; Djambatan.

Fardiaz, S. 1992. Mikrobiologi Pangan 1. Jakarta; PT. Gramedia Utama Pustaka 
Bivalen: Chemical Studies Journal, 2018, Vol. 1, No. 2

Hasanah, H, dkk. 2012. Pengaruh Fermentasi Terhadap Kadar Alkohol Tape Singkong. Vol.2. No. 1

Lingga, P dan Marsono. 1990. Petunjuk Penggunaan Pupuk (edisi IV). Jakarta; Penebar Swadaya

Novary, E. W. 1999. Penanganan dan Pengolahan Sayuran Segar. Jakarta; Penebar Swadaya

Rampengan, V.J dkk. 1985. Dasar-dasar Pengawasan Mutu Pangan. Ujung Pandang; Badan Kerja sama Perguruan Tinggi Negeri Indonesia Bagian Timur.

Retno, R. 2013. Pengaruh Pembungkus yang Berbeda Terhadap Kadar Etanol dan Ogranoleptik Tape Uwi (Dioscorea alata L). Skripsi. Jurusan Pendidikan Biologi. Fakultas Keguruan dan Ilmu Pendidikan. Universitas Muhammdiyah surakarta.

Rizani, K. Z. 2000. Pengaruh Konsentrasi Gula Reduksi dan Inokulum (Saccharomyces cerevisiae) pada Proses Fermentasi Sari Kulit Nanas (Ananas comsus L. Merr) untuk Produksi Etanol. Skripsi. Jurusan Biologi. Fakultas Matematika dan Ilmu Pengetahuan Alam. Universitas Brawijaya. Malang.

Syukri. 1999. Kimia Dasar. Bandung; UI Press.

Wanto, EP dan Arief Soebagyo. 1980. Dasar-dasar Mikrobiologi Industri. Direktorat Pendidikan Menengah Kejuruan, Dep Pendidikan dan kebudayaan.

Weny Andriani, dkk. 2015. Kajian Lama Fermentasi Terhadap Kadar Alkohol Tape Ketan Hitam (Oryza sativa glutinosa) Sebagai Pengembangan Lembar Kerja Siswa Pada Konsep Bioteknologi Konvensional Kelas XII SMA. Program Studi Pendidikan Biologi Fakultas keguruan dan Ilmu Pendidikan Universitas Riau. 